\title{
International Journal of Man
}

The Labour Market Impact of Covid-19: Early Evidence for a Sample of Enterprises from Southern Europe

\begin{tabular}{|r|l|}
\hline Journal: & International Journal of Manpower \\
\hline Manuscript ID & IJM-04-2021-0222.R2 \\
\hline Manuscript Type: & Research Paper \\
\hline Keywords: & Labor demand, Matching approach, labour hoarding, Covid-19 \\
\hline \multicolumn{2}{|l}{} \\
\end{tabular}




\title{
The Labour Market Impact of Covid-19: Early Evidence for a Sample of Enterprises from Southern Europe
}

\begin{abstract}
This study uses evidence from World Bank enterprise surveys of a sample of firms from six countries in Southern Europe. It examines the early evidence of the effects of Covid-19 on labour markets. The evidence and the analysis are provided at a time when the pandemic is still in progress. The future progress of Covid-19 and government containment measures is uncertain, and the full economic consequences will probably continue to emerge after the end of the pandemic. The full extent of the impact on labour will probably not be the first of these. Nonetheless the possibility of learning lessons from the early stages of the pandemic is sufficiently important to make the exercise valuable.

The study suggests that, despite efforts to support firms and hoard labour, there is a prospect of a significant number of firm closures with a consequent loss of employment. Temporary firm closures also represent a substantial loss of labour weeks. These are partly related to a significant number of workers subject to furloughs. Both temporary closures and furloughs impose costs that will be borne by firms, workers and government. The effects of Covid-19 on firms differ across sectors. Adverse effects tend to be higher in hospitality, non-essential retail and travel. A degree of gender segregation means that these are sectors with a high proportion of female workers and, in consequence, most of the countries in the sample exhibit an early decline of the share of women in employment. That many firms lack the capacity to survive further temporary closures of a similar duration to those in the earlier stages emphasises that the support provided in the near future is of critical importance to control employment losses through permanent firm closures.

The empirical findings suggest that Covid-19 cases and deaths have directly affected firm sales but government containment measures, particularly closures, have more strongly affected firms. Losses of sales were unsurprisingly related to losses of employment. Remote working has contributed to sustaining employment but online business has not affected most sectors.
\end{abstract}

Source: Enterprise Surveys, The World Bank, http://www.enterprisesurveys.org 


\section{The Labour Market Impact of Covid-19: Early Evidence for a Sample of Enterprises from Southern Europe}

\section{Introduction}

This study uses World Bank Enterprise Survey data to provide an early assessment of the economic impact of Covid-19 on a sample of six countries from southern Europe, particularly with respect to the impact on employment and gender. The choice of Southern Europe is partly based on the observation that the sample includes a number of countries whose economies faced more severe difficulties than elsewhere in Europe. Economically they were less able to absorb the economic shock posed by Covid-19. It is also partly based on the characteristics of the pandemic. A number of countries in the sample were amongst the earliest in Europe to be hit by the pandemic and a several were harder hit in terms of both morbidity and mortality than most other parts of Europe. The selection of our sample of countries was, therefore, based partly on underlying economic vulnerability and partly on early exposure to a high level of infections.

An obvious challenge is that it has been undertaken on data collected during the course of the pandemic. Events both in terms of morbidity and mortality and in the government containment response have tended to evolve rapidly. The full economic consequences will probably not be fully clear until long after the crisis is over. Nonetheless it seems evident to the authors that some analysis of the early stages in Southern Europe is of potentially importance. Learning lessons could help shape the response of business and government for the remainder of the pandemic.

The economic consequences potentially cover a wide range of issues. The focus of this study is on firm level evidence of the effect on labour. This also provides challenges in that the scope is still wide. The pandemic has accelerated practices such as remote working or on-line selling. Firm closures - permanent and temporary - have created losses in employment, temporary or otherwise. Practices (such as furloughs) that are new or otherwise have been rarely used in the past have come to the fore. The effects of many government measures to contain the virus have necessarily affected some sectors more than others, international travel and nonessential retail being examples. It is not just the governmental response but caution with respect to the virus that have affected firms and their employment from, say, hospitality or public transport.

Government support to firms and workers is a critical factor. Past temporary economic crises such as recessions have often resulted in labour hoarding. From the perspective of a shareholder view of the firm this can be rational. A long-term perspective suggests neither permanent closure nor laying off workers may be the best response to a temporary crisis in demand. A stakeholder model of the firm would often suggest that it is not an optimal for the point of view of workers or the wider economy either. Both imply a preference for labour hoarding. However, the economic effects of the Covid-19 crisis are deeper and more prolonged than any economic recession in recent history. The surveys also include information on how long firms believe they could survive without support if closed by virus containment measures. It is clear that many firms do not have the ability to survive for long. Whether one takes a shareholder or stakeholder view it is irrelevant if firms are forced into closure. Support from government or commercial loans to firms (and workers) is critical to avoid permanent losses in employment. It is probably not coincidental that, in the early stages, of the pandemic that Portugal had both a markedly higher rate of permanent firm Source: Enterprise Surveys, The World Bank, http://www.enterprisesurveys.org 
closures (with a resulting loss of employment) and a much lower rate of firms receiving or expecting government support than other countries in the sample. Much also depends on the details of government support in each country (which is outside the scope of the paper), but it is clear that gaps in or limitations to support will most likely create permanent closures. Temporary closures for virus containment purposes also impose costs which must be borne by government, firms or workers or some combination of the three.

The structure of the paper is as follows. Section 2 provides an overview of the stylized facts bases on the World Bank's own summary of the surveys. Section 3 comprises a review of the relevant literature. Section 4 provides details of the data used for analysis and section 5 the methodology. Section 6 provides a regression analysis of a number of employment related variables.

\section{Overview of the World Bank Enterprise Surveys}

The World Bank conducted standard enterprise surveys of Croatia, Cyprus, Italy, Malta and Portugal in 2019 and of Greece in 2018. After the Covid-19 outbreak they conducted two rounds of follow-up surveys to assess the impact of Covid-19. The effects of Covid-19 on the economy are already well known. News sources have reported firm closures (temporary and permanent), lockdowns, losses of sales, workers furloughed or made redundant, changes in working and liquidity problems. The existence of these problems is not in itself undocumented but, to date, there has been little systematic evidence of the extent of these. The enterprise surveys provide a systematic initial assessment. Although the focus of this study is the impact on labour and gender an understanding of the wider impact on firms is highly relevant. This section draws on the World Bank's own summary indicators of their Covid-19 surveys to provide an initial picture of many of the key characteristics of the impact of Covid-19 on firms in our sample of countries from Southern Europe. The purpose of this section of the paper is to present the "stylised facts" and the supporting evidence rather than analysis.

\subsection{Firm Closures}

Appendix 1 reports the summary indicators with respect to firm closures. The proportion of firms which are confirmed to have closed is typically very low, varying from a mean of $0.03 \%$ in Greece (November 2020) to 5.14\% in Italy (December 2020). These surveys were conducted at a comparatively early in the crisis and confirmation of a permanent closure often takes time. For these reasons they most likely significantly understate the likely true number of permanent closures. In all countries the two Covid-19 follow-up surveys used the same sample as the original enterprise survey. Despite there being a fairly short period since the original surveys there were many firms that could not be contacted. For that reason the World Bank's own summary contained two measures of permanent closures; (a) confirmed closures and (b) confirmed and assumed closed. The difference between the low proportion of firms confirmed permanently closed and those assumed closed is substantial, suggesting that employment losses from permanent closures are likely to be much more substantial that confirmed closures would suggest.

The follow up Covid-19 surveys used the same sample as the earlier enterprise survey so, for example, the follow up survey conducted for Cyprus in December 2020 found an overall average of $20 \%$ of the firms interviewed in the 2019 survey to be confirmed or assumed to be permanently closed. The comparable proportion was much lower for Malta (1.59\% in January 2021) and Greece (6.87\% in November 2020) but much higher for Italy (36.14\% in December 2020) and Portugal (23.62\% in October 2020). It is, of course, the case that there would have Source: Enterprise Surveys, The World Bank, http://www.enterprisesurveys.org 
been a number of permanent closures even without Covid-19 when revisiting a number of firms after approximately 12 months and it is likely that some assumptions of permanent closure were incorrect. Nonetheless that more than one third of Italian firms and about one quarter of Portuguese were assumed or confirmed closed greatly exceeds what might be expected from normal casualty rates. The evidence is too early to be conclusive but does suggest that we should expect a high proportion of permanent firm closures as more information emerges.

Across the five countries there is no real consistent differences according to firm size. Small firms do seem to have been a more prone to assumed permanent closure than large firms in every country other than Croatia. Services, as one might expect, exhibit a higher proportion of assumed permanent closures than manufacturing in every country except Cyprus. Retail had a higher assumed permanent closure rate than other services for Croatia, Cyprus and Italy but a lower rate in Portugal. Direct exporters were more heavily represented in permanent closures than non-exporters in Croatia, Cyprus and Portugal but the reverse was the case in Greece and Italy. Firms with $10 \%$ or more foreign ownership exhibited a markedly higher proportion of assumed permanent closures than domestic firms for Cyprus, Italy and Portugal but not for Croatia or Greece.

The surveys show that a high proportion of firms in each country had experienced temporary closures at some time since the onset of Covid-19. These vary from just under $30 \%$ of responding firms in Croatia and Malta to about $66 \%$ in Italy, just under $50 \%$ in Greece and approximately $45 \%$ in Cyprus. The average duration of these closures also varied by country from about 6 weeks for Portugal and 7 weeks in Croatia to around 10 weeks in Cyprus, Greece and Italy. Comparable data was not reported for Malta.

In all countries except Cyprus a markedly higher proportion of small firms than medium sized firms and of medium sized firms compared to large firms were subject to temporary closures. The data do not offer direct evidence, but this may be related to the sectors most likely to be targeted for temporary closures. For example, the hospitality sector might be expected to have a higher proportion of small firms than most other sectors. This is partly supported that the results show a markedly higher proportion of firms in services than in manufacturing were subject to temporary closures (except in Cyprus). For both Cyprus and Greece temporary closures were much more prevalent in the retail sector than for other services The reverse was the case for Croatia, Italy and Portugal. Non-exporters were more likely, in most cases much more likely, to have experienced temporary closures than non-exporters. A higher proportion of firms with $10 \%$ or more foreign ownership were subject to temporary closures than domestic firms in Croatia and Cyprus but the reverse was true for all other countries.

\subsection{Changes to the Way of Working}

It is obvious from news reports that Covid-19 has not just changed the levels of business for firms or whether they do business at all but also the way in which they do it. Appendix 2 presents some details from the surveys of our sample of countries from Southern Europe. The proportion of firms that had started or increased online business activity varied from about $13 \%$ of the sample in Croatia and Portugal to up to just under $30 \%$ in Greece. For most countries medium sized firms were the most common developers of online business with Croatia and Portugal being exceptions. Firms in services tended to have been more likely to have developed online business than manufacturing.

With the exception of Croatia ( $4.5 \%$ of firms) a substantial proportion of firms in every one of the sample countries introduced or increased delivery as part of their business. The proportions varied from about $17 \%$ in Malta to about $30 \%$ of the full sample for Greece. In Source: Enterprise Surveys, The World Bank, http://www.enterprisesurveys.org 
Cyprus and Greece this was most prevalent among medium sized firms and in Italy, Malta and Portugal amongst small firms. As one might expect direct exporters exhibited a much lower proportion of firms extending or introducing delivery than those supplying domestic markets only.

In each of the sample countries a significant, often substantial proportion of firms either introduced or increased remote working. The lowest proportion was about $18 \%$ of the full sample for Portugal and the highest $47 \%$ for Malta. In most countries the larger the firm size the greater the proportion of firms resorting to new or extended remote working. That is, the proportion of medium sized firms making more use of remote working tended to be higher than for small firms and the proportion of large firms higher than for medium ones. Services other than retail exhibited a greater share of firms more engaged with remote working than either retail or manufacturing. Firms involved in direct exports and those with $10 \%$ or more foreign ownership also tended to develop remote working to a substantially greater extent than those that did not. Evidence exists - see Böckerman and IImakunnas (2012) - that an increase in remote working could have benefits for recovery from the current crisis. They find that remote working increases both job satisfaction and performance.

\subsection{The Impact on Employment}

Again, there can be little doubt not just from news media but also from official statistics that the pandemic has significantly affected employment. The impact upon employment from the perspective of firms in the World Bank Surveys for our sample of countries in Southern Europe is presented in Appendix 3. A significant number of firms in the surveys had increased their permanent workforce since December 2019. In the full sample for Croatia only just under $4 \%$ of firms had increased their permanent workers but this proportion was substantially higher in all the other countries, ranging from about $12 \%$ in Malta and Italy to about $30 \%$ in Cyprus and Greece. However, the proportion of firms who had decreased their permanent employment was, for every country (except Cyprus) substantially higher - Croatia (12\%), Greece (42\%), Italy (29\%), Malta (20\%) and Portugal (17\%). This means thar, in the full sample for each country), firms who decreased permanent employees greatly exceeded those that increased them (with one exception). The gap between the proportion of firms decreasing permanent employees was substantially greater for small firms in Croatia, Greece and Italy but significantly greater for large firms in Malta and Portugal. The difference between firms decreasing permanent employment and those increasing it was greater for manufacturing than for services in all countries except Greece and Cyprus.

That some firms reduced employment at the same time that others increased it in response to the Covid-19 crisis implies that, despite an overall reduction in employment, there has been some worker reallocation between firms and between sectors. A counter-cyclical reallocation effect has long been recognised in the literature - for example by Davis and Haltiwanger (1999) and Haltiwanger et al (2014). The data used here show a similar effect from the Covid19 crisis.

A similar picture emerges with respect to temporary workers. In all of the sample countries a comparatively small proportion of firms had increased temporary employment at some stage since the onset of Covid-19. For the full sample the proportion varied from $0.2 \%$ in Croatia to around $7 \%$ in Italy. Again, the proportion of firms which had decreased temporary employment at some stage was much higher than those who had increased it in every country except Portugal. The difference between the two percentages was highest in Greece $(15 \%$ of firms) and Malta (13\%) and lowest in Croatia (5\%) and Italy (8\%). In all countries except Greece and Portugal large firms (compared to small and medium) had a much higher Source: Enterprise Surveys, The World Bank, http://www.enterprisesurveys.org 
difference in proportion of firms that had decreased temporary employment and those that had increased it.

\subsection{Gender}

Survey details of changes of the share of females in permanent full-time employment and in the workers furloughed are presented in Appendix 4. In the full sample for 4 countries Croatia, Cyprus, Greece and Portugal the surveys suggest Covid-19 to have reduced the firm average share of females in permanent full-time employment. In Italy and Malta, the comparable share increased.

\subsection{Government Support}

Appendix 5 shows that, in the full sample for each country, a high proportion of firms have either received or expect to receive some form of support from national or local government. The only country where the proportion of such firms is under $60 \%$ of the full sample is Portugal (just under 31\%). The remainder vary from about $61 \%$ (Croatia) to $84 \%$ (Greece). Support tends to be higher for manufacturing than services and lower for retail and for other services.

\subsection{Summary of Relevant "Stylised Facts" from the Surveys}

- It is too early to be certain, but it seems highly likely that Covid-19 has resulted in a substantial proportion of firms having been closed permanently, particularly in Portugal.

- A high proportion of firms have been subject to temporary closures. In many cases the duration of these closures has been close or in excess of the maximum period that firms could survive without either sales or support.

- A significant proportion of firms have changed their way of operating to introduce online business, delivery or remote working. These adaptations must have helped reduce the impact of adverse effects on employment.

- In most cases a much larger proportion of firms have decreased employment permanent and temporary - than have increased it.

For the sample of firms in Southern Europe the share of females in permanent employment decreased in four of the countries but increased in firms from Italy and Malta

- In almost all countries a high proportion of firms either received or expected to receive government support. The number of firms having received or expecting to receive government support was substantially lower in Portugal. It is worth repeating that Portugal also experienced the highest rate of permanent firm closures.

\section{Review of Literature}

The adverse economic impact of COVID-19 varies across countries and sectors with some more negatively impacted than others (World Bank, 2020; Hevia and Neumeyer, 2020; WTO, 2020a, b; Baldwin and Freeman, 2020; Baldwin and Tomiura, 2020; Lakatos, 2020). There is a growing body of academic literature that has investigated the macroeconomic effects of COVID-19 across countries, focussing on US, UK, Germany, Japan, as well as developed and developing countries, and sectors (see Hayakawa and Mukunoki, 2020; Friedt and Zhang, 2020; Maliszewska, et al. 2020; Ozge at al., 2020). Studies discuss the transmission of the shock that affected international flows of intermediate inputs which impacted global 
demand, production, consumer spending and investment (Correia et al., 2020; Espitia et al., 2021). Social distancing measures that were imposed by developed and developing countries to control the spread of the pandemic reduced labour supply and increased the cost of production (Espitia et al., 2021; McKibbin and Fernando, 2020).

Studies focussing on the microeconomic impact of COVID-19 suggest that the impact of the crisis is likely to be severe for small and medium enterprises (SMEs) as these primarily exist in the hardest-hit sectors, such as hotels, food services, wholesale and retail services (OECD, 2020b). SMEs have been highly vulnerable to lockdown measures and the negative impact has been magnified due to their limited access to commercial financing (WTO, 2020b). In general, SMEs can be severely affected by major disruptions that require a high degree of resilience, for instance, during acute economic crises (Pal et al., 2014). SME entrepreneurs are known for their capabilities that enable their firms to be resilient, having themselves directly experienced adversity, or operated in uncertain environments (Branicki et al., 2018). Some suggest that the SMEs may be able to survive the current COVID crisis given small firms have direct experience to adapt and deal with adverse situations (see Kuckertz et al., 2020 on Germany; Eggers, 2020 on SMEs in general).

The literature on how SMEs employees have been affected by the pandemic is emerging. The general view is that the pandemic is likely to pose a risk to SMEs survival in sectors such as hotels, food services, wholesale and retail services, with detrimental impact on employees (OECD, 2020b; Gossling et al., 2020; Hassan et al., 2020). These findings apply to all countries in general. Studies show that labour hoarding is accomplished through an adjustment of the number of employees to production changes particularly during global crises and due to any vital changes in national economies (Radlińska et al., 2020). In the macroeconomic models of the labour market, labour hoarding is part of the demand for labour (Ehrenberg \& Smith, 2012; Vella, 2018), this can be observed in companies in a good financial condition and depends on the expectations of enterprises about the duration of the slowdown. But labour hoarding which has implications for the shareholder and stakeholder approaches does not hold in the current crisis when labour hoarding cannot be used to optimise decisions regarding employment costs, training and dismissals. In reaction to the COVID-19 crisis, businesses have chosen to implement furloughs as a means to keep their businesses viable in the short-term and hopefully retain talent and maximise flexibility (Wolf, 2020).

High and medium-income developed and developing countries have put in place countercyclical monetary and fiscal policies, and while such policies have been beyond most lowincome developing countries with limited public finances the spotlight has been shone on the labour theory. Earlier studies on the employment effects of SARS and MERS find that shorttime work could be an effective measure to prevent job losses in severe recessions (Balleer et al., 2016), this may though not hold in the current situation. This is because the magnitude of the employment losses from the COVID pandemic differ substantially across different types of jobs and different types of workers. Studies examining the link between occupational characteristics and employment confirm that some occupations that are likely to be at risk due to social distancing requirements are adversely impacted (Dingel and Neiman, 2020). Using employment classifications, Montenovo et al. (2020), Mongey et al. (2020) and B'eland et al. (2020) find evidence of better labour market outcomes for workers in occupations that were more likely to be able to work from home or were less likely to have to work in close proximity to others, these studies report findings from the US and Canada.

Source: Enterprise Surveys, The World Bank, http://www.enterprisesurveys.org 
Cortes and Forsythe (2020) find substantially larger employment losses in low-paying occupations and industries in the US. Workers employed in lower paying occupations and industries have been disproportionately impacted, given that employment declines have been significantly larger among lower-paying job categories. These asymmetric occupationand industry-level effects may reflect heterogeneities in the extent to which different jobs can be performed remotely (see Dingel and Neiman, 2020), as well as differences in which types of businesses have been allowed to continue to operate during the pandemic. Further some groups of workers are more affected than others. For example, individuals from Hispanics groups, younger workers and those with lower levels of education including women have been disadvantaged and suffered larger increase in job losses and larger decrease in hiring rates. Montenovo et al. (2020) also report similar results that unemployment increased among Hispanics, workers aged 20 to 24, and those with high school degrees and some college. Similar findings emerge from Cajner et al. (2020) who use data from ADP, a large U.S. payroll processing company.

Studies confirm the negative impact of COVID-19 on production and employment. For example, Dias et al (2020) use real time survey evidence and examine how COVID-19 impacted the labour market in the UK, US and Germany. Though the results vary across countries and sectors an interesting finding is that less educated and younger workers as well as women are more likely to be more adversely affected. Germany, however, is less likely to impacted primarily due to the short-time work scheme but this may not be the same for other countries. COVID-19 increased the unemployment rate and there has been growing unemployment support claims in the US (BLS, 2020; Dais et al. 2020).

Matthias and Tertilt (2016) examine the implications of the pandemic on gender and report that compared to "regular" recessions, which affect men's employment more severely than women's employment, the employment drop from social distancing measures has had a large impact on sectors which have high female employment. Borland and Charlton (2020) examine labour market outcomes by gender for Australia and report that females were more adversely impacted than males by the decrease in labour demand following the onset of COVID-19. The closures of schools and day-care centres increased childcare needs which had a large impact on working mothers. As Coskun and Dalgic (2020) use US data to explain that men mostly work in industries heavily affected by a "standard" downturn (such as manufacturing and construction) while women employment is concentrated in less cyclical sectors, such as health care, retail and education. Though historically cyclical downturns do not exacerbate the gender aspect the current crisis has impacted service sectors with high female employment shares, such as restaurants and hospitality, highlighting the gender dimension of the crisis. Borland and Charlton (2020) also examine the labour market outcomes by gender for Australia and report that females were more adversely impacted than males by the decrease in labour demand following the onset of COVID-19 although the gap in outcomes narrowed as recovery commenced. Females were also more likely than males to withdraw from the labour force. The WTO (2020b) also suggests that women may suffer disproportionately, because the sectors in which they are economically active are among those which have been the worst affected by the COVID crisis e.g., apparel and footwear, tourism and other commercial services.

\section{Data}

Source: Enterprise Surveys, The World Bank, http://www.enterprisesurveys.org 
The data for the study were taken from three different sources. The source for the firm level data was: Enterprise Surveys, The World Bank, http://www.enterprisesurveys.org. For each of the countries in our sample there were three separate surveys - an initial enterprise survey conducted in 2019 (2018 for Greece). For the same sample the World Bank then conducted two rounds of follow-up surveys on the effects of Covid-19. Details of the questionnaires, sampling procedures and other documentation are available from the enterprise surveys website. The dates of the first and second rounds of these follow-up surveys were:

- Croatia - September 2020 and January 2021

- Cyprus - June 2020 and November 2020

- Greece - June 2020 and November 2020

- Italy - May 2020 and October 2020

- Malta - October 2020 and January 2021

- Portugal - September 2020 and December 2020/January 2021

Given the speed with which the pandemic itself and the containment response by governments has changed differences in the timings of firms' responses are worth noting. Daily data on government containment policy and its stringency was obtained from the Oxford Covid-19 Government Response Tracker: COVID-19 Government Response Tracker 1 Blavatnik School of Government (ox.ac.uk). These data comprise an overall Containment and Health Index which measures the strength of response of each government and encompasses the Stringency Index. These are constructed from a number of sub-indices constructed on a range of indicators on the stringency of, for example, work closures, restrictions on internal movement, controls on public gatherings and income support measures. These data are at the country level but we matched the data to the exact date of interview for each firm. This ensured that, for each firm, government response measures were as the date of interview. To our overall data we also added daily data on the pandemic in each country such as cases per million and mortality. These were obtained from: Coronavirus Pandemic (COVID-19) Statistics and Research - Our World in Data As with the response data these were matched with the exact date of interview with the firm such that the then current national state of the pandemic was included.

There are two key problems with any analysis of the economic impact of Covid-19 on employment in firms. The first is that, as discussed in the introduction, neither the pandemic nor its economic consequences have yet run their full course. The second is that it is unprecedented within living memory. This second problem means that there is no clear theoretical economic model with explicit predictions to test. There is a rapidly growing but still very under-developed empirical literature. This provides only a limited template for how to focus research.

Within our data set we defined four sets of possible influences affecting firm behaviour in response to Covid-19, particularly with respect to employment. These are:

1. Firm characteristics based on the initial survey preceding Covid 19. These include, for example, sector, firm size, performance, debt and managerial experience. This allows for the analysis to include differential effects by sector and size and to allow the possibility that some firms were better placed to ride the storm.

2. Firm responses to the Covid-19 crisis as revealed in the two follow-up surveys. These include, for example, the number of weeks the firm was temporarily closed, the 
number of workers furloughed, the increased use of remote working and the receipt of government support.

3. Government containment measures. These include workplace closures, restrictions on movement and income support.

4. The spread of the pandemic itself. Although some containment measures clearly and directly affect firms it is not just the response but also the reaction of the population of the population to the pandemic that affects firms. For example, Covid-19 has moved consumer preferences in favour of online and delivery and accelerated remote working.

For each of the surveys (original enterprise survey and both Covid-19 follow-up surveys) for each of the six countries implementation reports are available from the same source as the survey data. These discuss how weights were derived and discuss non-response issues. The sample for the original enterprise survey was a stratified random sample and the two followup Covid-19 surveys continued to use the same sample. There is no easy way to adequately summarise a total of 18 different implementation reports. Non-response issues exist for each country and survey at two levels - non-response to the survey as a whole and non-response to individual questions. Readers interested in non-response issues are referred to the implementation reports which discuss these. The implementation reports also discuss limitations with the weights provided. Given these issues and that the data for this study was combined with data from other sources the analysis in this study did not use weights. This means that conclusions from our sample do not necessarily hold at the level of underlying population.

Descriptions of the variables included in the regression models are in all cases provided with the results. One variable requires a little more clarification. The World Bank surveys divide firms into several size classes, each of which is defined by the number of employees. To avoid using a discrete measure of firm size the study simply used the number of full-time employees in 2019 as a continuous measure of firm size.

The absence of theoretical models to narrow the focus of an applied economic model and the very limited precedents from earlier studies mean that there are a large number of variables that cannot be excluded from any analysis. The unprecedented nature of the pandemic means that there is a lack of an initial focus because there is no existing focus to follow. This necessarily creates an unfocused and long list of variables with the focus to be provided empirically. That is, the focus is provided, in no small part, by working from general to specific as discussed in the following section.

\section{Methodology}

This study faces two important challenges. Firstly, it is written before the pandemic is over and events have changed rapidly. The economic impact will undoubtedly be felt over a longer period. Efforts to preserve jobs through, for example, furloughs and measures to prevent permanent closures of firms may succeed to a point but it is unlikely that the full extent of long-term effects on employment are yet clear. Although this is a challenge it is also a key objective of the paper - to establish what the early lessons can tell us for the remainder of the pandemic and its economic aftermath. For example, what do early permanent closures of firms tell us about reducing the risk of job losses from the failure of firms?

Source: Enterprise Surveys, The World Bank, http://www.enterprisesurveys.org 
The second challenge arises because the pandemic is unprecedented in living memory. There is no clearly specified theoretical model which tells in detail how the impact on employment should be expected. That is, there is not a clear and detailed model to be tested. Indeed, some of the relevant phenomena such as furloughs are more or less without precedent. The first step in our analysis is simply to provide summary data analysis from the enterprise and Covid19 follow up surveys. This helps to clarify the importance of issues such as temporary firm closures.

It is not at all unusual in applied econometric studies to estimate a relationship where the underlying theoretical data generating process is not clearly specified in advance by theory or the precedent of previous studies. The method of working from general to specific - see, for example, Campos et al (2005) - has been in widespread use for some time. Put simply it is often the case that we do not have a sufficiently well specified data generating process in advance such that we know which explanatory variables to include in a model and which to exclude. This makes it the job of the researcher to provide evidence as to which are relevant, and which are not. Exclusion of a relevant (confounding) variable risks the estimates being biased (endogeneity). Including variables that do not contribute to the explanation increases the variance of the model and reduces the precision of subsequent tests. This means that redundant variables need to be removed. The general to specific approach starts by including all explanatory variables of potential relevance and then works to a more specific model by using redundant variable tests to exclude those that are jointly statistically insignificant.

This study includes regression analysis using both probit and least squares. These address six questions related to employment:

- What aspects of the Covid-19 crisis are most important in explaining changes in firm sales (and, hence, the demand for labour)?

- What determines the probability of firms permanently closing, with resultant job losses?

- Which factors most influence workers decisions to take leave or to quit their jobs in response to Covid-19?

- How is the number of workers furloughed related to the pandemic, the containment response and firm characteristics?

- What determines firms' expectations of the length of time they could survive without sales or support?

- Which are the main causes of changes in the share of females in employment during Covid-19?

As explained in the preceding data section there exist a large number of variables that are of potential relevance encompassing firm characteristics before the pandemic, firm responses to it, country and date specific containment measures and morbidity and mortality of the pandemic itself. There exists no clear and detailed model of the data generating process which can simply be tested. These questions require a general to specific approach. It is important to note that such an approach is not only distinct from "data mining" but, in most cases, superior to it - see Hoover and Perez (1999).

These questions are intended to address the capacity of firms to sustain employment in the longer term and provide a basis for recovery. The presence of, for example, temporary support measures and furloughs means that it is not easy to identify employment effects

Source: Enterprise Surveys, The World

Bank, http://www.enterprisesurveys.org 
whilst the pandemic is still in progress, but it is possible to develop an understanding of the early impact on ability of firms to sustain employment to the end of the crisis.

In the main regression analysis is by means of Ordinary Least Squares (OLS) and by probit for the probability of permanent firm closure. However, the likelihood of endogeneity from a two-way causality between two of our dependent variables of interest - workers leaving and being furloughed - required a different approach. For these two variables we used a Seemingly Unrelated Regression Equations (SURE) approach first proposed by Zellner (1963)

The SURE estimator is not identified if both equations have an identical set of explanatory variables. This means that restrictions excluding one or more variables from each equation need to be imposed. In the process of working from general to specific these exclusion restrictions were tested in the normal way. At the starting point - the general model - this is not possible and the initial exclusion restrictions are typically imposed on theoretical grounds. Since the pandemic is unprecedented there is very little that exists for formal theoretical predictions. But there are conceptual grounds for such exclusions. For this paper we define a "furlough" to be a temporary lay-off of an employee, whose wages are partly paid by the firm or by government or both. This decision is taken by the firm and does not always require the employee's consent. In contrast a decision to quit the firm or to request leave is initiated by the employee not the firm, although the firm can decline to grant leave. This means that there are three categories of explanatory variables - (a) variables which could plausibly and materially affect firm decisions but not those of employees, (b) variables that could plausibly affect the employee's decision but not that of the firm and (c) variables that could plausibly and materially affect both. Variables that were defined in category a were included in the equation for furloughs but excluded from the equation for "leave". Examples included the firm's debt leverage prior to the pandemic and whether or not the firm faced a decline in liquidity. Variables in category b were included in the equation for "leave" but not that for furloughs. Examples included the degree of government restriction on public transport and restrictions on international travel. These initial exclusion restrictions meant that the general model was identified.

To summarise the approach of this study is founded on several propositions. Firstly, an analysis of the economic (employment) impact of Covid-19 faces obvious difficulties whilst the eventual outcome is unknown but the possibility that an early assessment might provide useful insights is worth these risks. Secondly, there is neither an adequately detailed theoretical model nor a sufficient body of existing empirical research to allow simple testing of a well specified model. Given the unprecedented nature of the pandemic it is inevitable that a general to specific approach would be needed. Finally, working with enterprise level data always poses issues of sample heterogeneity and is one limitation to the study. A regression approach is used to provide a general representation of behaviour for the whole sample but there is much variation between firms that remains unexplained.

\section{Analysis}

\subsection{Overview of Employment Related Enterprise Level Effects of Covid-19}

Table 1 presents data based on the responses of individual enterprise to the round 1 and round 2 follow-up Covid-19 surveys. All figures are presented as a proportion of the full-time permanent employees recorded in the full enterprise survey conducted before the onset of Source: Enterprise Surveys, The World Bank, http://www.enterprisesurveys.org 
the pandemic (in 2018 for Greece and in 2019 for all other countries). The table needs careful interpretation. Events have tended to change rapidly, both in terms of the pandemic itself and in terms of the responses of governments and businesses. The Covid-19 follow-up surveys were not conducted simultaneously. The round 2 survey interviews were conducted in January 2021 for Croatia, late December 2020 and early January 2021 for Portugal, January 2021 for Malta November 2020 for Greece and for Cyprus and during October and early November 2020 for Italy. This means, for example, there is a gap of over two months between enterprise responses from Italy and Portugal.

Permanent closures of firms have clear employment implications, namely a $100 \%$ loss of the enterprise's jobs. Firms recorded as permanently closed by the follow-up surveys represented $11.1 \%$ of the total full-time permanent workforce at the time of the full enterprise survey in 2019 (2018 for Greece). A significant number of firms who participated in the full survey could not be contacted for the follow-ups. Many of these are likely to also have been permanently closed. This means that the losses of employment in Table 1 most probably under-state the true position. Even putting this aside a loss of $11 \%$ of employment is far from trivial.

There is considerable variation in the employment implications of permanent firm closures between countries, some of which might be explained by differences in the timing of interviews. Permanent closures of firms represented only a modest loss of employment for most countries except Portugal at $23.5 \%$. Overall, the loss of female employment from closures was greater for females at $13 \%$. For all countries other than Greece or Portugal the loss of female employment was lower than for overall employment.

Large firms tended to be less prone to permanent closures than small or medium sized for both overall and female employment. Enterprises with foreign ownership were less likely to lose employment from permanent closure than domestic firms and exporters less likely than non-exporters. Firms with a female top manager also were much less likely to lose jobs from permanent closure than those with a male top manager.

One of the follow-up survey questions was: ${ }^{1}$

"...how many workers have taken leave for more than 5 days or quit due to illness, childcare interruption, or mobility restrictions linked to the COVID-19 outbreak?"

The responses suggest that a non-trivial proportion of the pre-COVID-19 workforce either left their jobs or took leave as a consequence of the pandemic. The proportion of females (10.2\%) was substantially higher than for both genders (4.2\%). The proportion so doing was substantially higher for females in particular in (a) food retail and pharmacies and (b) hospitality. The proportion of the workforce that were laid off by firms was low overall $(0.8 \%)$ and low in each country but higher for females (1.4\%) than males.

At different times a high proportion of the labour force had been subject to furloughs $-18.5 \%$ of workers at the time of the first follow-up survey and nearly one third of females. Furloughs were not widely used in either Croatia or Malta but much more extensively used in all other countries. The proportion of females furloughed was very much higher in Greece and Portugal.

Table 1: Firm Closures, Leave, Exits. Lay-offs and Furloughs

\footnotetext{
${ }^{1}$ We thank the Enterprise Analysis Unit of the Development Economics Global Indicators Department of the World Bank Group for making the data available. Source: Enterprise Surveys, The World
} Bank, http://www.enterprisesurveys.org 


\begin{tabular}{|c|c|c|c|c|c|c|c|c|}
\hline \multirow{3}{*}{ Sample } & \multirow{2}{*}{\multicolumn{2}{|c|}{$\begin{array}{c}\text { Permanent Firm } \\
\text { Closures }\end{array}$}} & \multirow{2}{*}{\multicolumn{2}{|c|}{$\begin{array}{c}\text { Workers Quiitting or } \\
\text { Taking Leave }\end{array}$}} & \multicolumn{2}{|c|}{ Lay-offs } & \multirow{2}{*}{\multicolumn{2}{|c|}{$\begin{array}{l}\text { Furloughs at time } \\
\text { first Covid-19 surve }\end{array}$}} \\
\hline & & & & & \multirow[b]{2}{*}{ all } & \multirow[b]{2}{*}{ female } & & \\
\hline & all & female & all & female & & & all & fem \\
\hline Full Sample & $11.1 \%$ & $13.2 \%$ & $4.2 \%$ & $10.2 \%$ & $0.8 \%$ & $1.4 \%$ & $18.5 \%$ & 32. \\
\hline Croatia & $2.0 \%$ & $0.8 \%$ & $4.9 \%$ & $10.2 \%$ & $0.8 \%$ & $1.5 \%$ & $0.9 \%$ & 1.7 \\
\hline Cyprus & $2.2 \%$ & $0.0 \%$ & $6.8 \%$ & $6.9 \%$ & $0.3 \%$ & $0.0 \%$ & $18.6 \%$ & 13.1 \\
\hline Greece & $0.0 \%$ & $0.1 \%$ & $3.2 \%$ & $16.4 \%$ & $0.4 \%$ & $1.2 \%$ & $23.8 \%$ & 88 \\
\hline Italy & $4.5 \%$ & $2.7 \%$ & $3.2 \%$ & $5.5 \%$ & $0.2 \%$ & $0.2 \%$ & $29.2 \%$ & 33.1 \\
\hline Malta & $2.1 \%$ & $0.0 \%$ & $5.4 \%$ & $6.0 \%$ & $2.0 \%$ & $1.9 \%$ & $0.9 \%$ & 0.9 \\
\hline$(\sqrt{2}-8$ & $23.5 \%$ & $25.7 \%$ & $4.5 \%$ & $13.5 \%$ & $1.3 \%$ & $2.4 \%$ & $19.5 \%$ & $45 . !$ \\
\hline Small (5-19 employees) & $14.4 \%$ & $16.6 \%$ & $20.8 \%$ & $7.7 \%$ & $4.3 \%$ & $0.9 \%$ & $77.7 \%$ & 19. \\
\hline Medium (20-99 employees) & $14.6 \%$ & $17.6 \%$ & $5.7 \%$ & $7.9 \%$ & $1.5 \%$ & $1.7 \%$ & $30.3 \%$ & 35.1 \\
\hline Large (100+ employees) & $9.9 \%$ & $11.9 \%$ & $2.5 \%$ & $18.2 \%$ & $0.3 \%$ & $1.8 \%$ & $10.6 \%$ & 55. \\
\hline $10 \%$ or more foreign ownership & $8.7 \%$ & $9.2 \%$ & $2.5 \%$ & $8.6 \%$ & $0.3 \%$ & $1.8 \%$ & $9.4 \%$ & 52. \\
\hline Domestic ownership & $11.7 \%$ & $14.2 \%$ & $4.4 \%$ & $10.3 \%$ & $1.5 \%$ & $1.7 \%$ & $20.9 \%$ & 31. \\
\hline Exporters & $10.6 \%$ & $12.7 \%$ & $3.2 \%$ & $10.2 \%$ & $0.7 \%$ & $1.8 \%$ & $13.6 \%$ & 33. \\
\hline Non-exporters & $12.0 \%$ & $16.0 \%$ & $5.9 \%$ & $10.1 \%$ & $1.0 \%$ & $1.1 \%$ & $26.4 \%$ & 32 \\
\hline Male top manager & $11.8 \%$ & $13.7 \%$ & $4.1 \%$ & $10.0 \%$ & $0.7 \%$ & $1.2 \%$ & $18.2 \%$ & 32. \\
\hline Female top manager & $6.3 \%$ & $9.7 \%$ & $5.6 \%$ & $11.4 \%$ & $1.3 \%$ & $2.3 \%$ & $21.6 \%$ & 32. \\
\hline Food retailers and pharmacies & $* *$ & $* *$ & $9.2 \%$ & $44.5 \%$ & $0.5 \%$ & $1.0 \%$ & $18.4 \%$ & 58. \\
\hline Other retailers & $* *$ & $* *$ & $3.2 \%$ & $4.1 \%$ & $0.9 \%$ & $1.1 \%$ & $34.0 \%$ & 41. \\
\hline Passenger transport, travel agencies, tour operators & $* *$ & $* *$ & $3.2 \%$ & $5.9 \%$ & $2.0 \%$ & $2.4 \%$ & $31.5 \%$ & 43. \\
\hline Hotels, bars, restaurants & ** & $* *$ & $5.9 \%$ & $20.2 \%$ & $1.5 \%$ & $3.2 \%$ & $10.2 \%$ & 26.6 \\
\hline
\end{tabular}

* measured as a percentage of employment from the full enterprise survey conducted in 2019 (2018 in Greece)

** Sample size too small to be reliable

Sources: World Bank enterprises surveys and follow-up Covid-17 surveys rounds 1 and 2

Table 2 presents details of the effects of temporary closures. Across the sample firm were temporarily closed for an average of 2.5 weeks, much longer for Malta in particular. Closures tended to be longer for non-essential retailers, passenger travel and for hospitality. Using the full enterprise surveys taken before Covid-19 the weeks of closure for each firm were converted into the implied number of labour weeks lost to temporary closures. Unsurprisingly the same weeks of closure for a large firm results in a much larger loss of labour weeks than for a small one. Equally unremarkably the longer periods of closure for non-essential retail, travel and hospitality also resulted a larger loss of labour weeks. The overall loss of labour weeks is not trivial. On average the loss of labour weeks is roughly equivalent to the loss of more than 3 full-time workers per firm. Depending on the schemes involved (if any) the financial loss involved is shared by the individual worker, the firm and government.

Table 2: Temporary Workplace Closures 


\begin{tabular}{|l|c|c|}
\hline & \multicolumn{2}{|c|}{ Average of: } \\
\hline Sample & Weeks firm & labour weeks \\
\hline Full Sample & closed & 160.6 \\
\hline Croatia & 2.5 & 184.2 \\
\hline Cyprus & 2.5 & 356.9 \\
\hline Greece & 6.2 & 226.8 \\
\hline Italy & 3.9 & 240.0 \\
\hline Malta & 3.2 & 247.7 \\
\hline Portugal & 10.6 & 85.0 \\
\hline Small (5-19 employees) & 1.4 & 27.5 \\
\hline Medium (20-99 employees) & 2.8 & 94.0 \\
\hline Large (100+employees) & 2.2 & 522.3 \\
\hline $10 \%$ or more foreign ownership & 2.2 & 325.7 \\
\hline Domestic ownership & 2.7 & 146.8 \\
\hline Exporters & 2.5 & 227.3 \\
\hline Non-exporters & 2.3 & 111.8 \\
\hline Male top manager & 2.6 & 158.0 \\
\hline Female top manager & 2.4 & 175.4 \\
\hline Food retailers and pharmacies & 2.7 & 98.0 \\
\hline Other retailers & 1.8 & 268.5 \\
\hline Passenger transport, travel agencies, tour operators & 4.1 & 443.4 \\
\hline Hotels, bars, restaurants & 5.7 & 504.4 \\
\hline Sources: World Bank enterprises surveys and follow-up Covid-17 surveys rounds 1 and 2 \\
\hline S. & 6.4 & \\
\hline
\end{tabular}

\subsection{Regression Analysis}

This section provides details of our regression analysis. As explained the data and methodology section that the pandemic is both unprecedented and on-going means that there is not a clearly specified theoretical model which provides detailed guidance on the appropriate choice of individual explanatory variables. There are a large number of possible choices at both the firm and country level. From a statistical point of view it is necessary to work from general to specific. An omitted (confounding) variable could result in biased estimates. To reduce this risk the approach was to start with a general model, to test for redundant variables and then re-estimate the model without them. Only these "specific models" are reported here. However, this means that a large number of variables were found to be redundant for each regression model. In some cases it is noteworthy that a particular variable had no statistically significant effect. To ensure that these are not overlooked noteworthy redundant variables that were omitted during the process are also reported.

As discussed in the data section country level variables (such as Covid-19 responses and Covid19 infections) were measured at the exact date of the round 2 follow-up interview for each firm. This means that they do vary between firms in the same country. All initial specifications were tested for heteroskedasticity and, where present, robust standard errors used. Since the exclusion of redundant variables was based on an F-test, variables with are not individually significant according to a t-test remain included in a few cases.

As shown earlier firm closures, both permanent and temporary, have potentially important and direct consequences for employment. Table 3 presents a probit analysis of firms from the Covid-19 follow up surveys. The results suggest that the marginal effect on probability of permanent closure is higher for (smaller) firms with few employees. This effect is statistically 
significant at $95 \%$ confidence but of a small magnitude. The experience of the firm's top manager has a statistically significant (but only at $90 \%$ confidence) and positive effect on the probability of closure. Again, this effect is of small magnitude. Of much more substance is the effect of the firm being in the hospitality sector (hotels, bars and restaurants). The marginal effect on probability of permanent closure is statistically significant at $99 \%$ confidence and of some consequence.

The probability of permanent closure is much affected by the responses of government to Covid-19. Restrictions on (a) public transport (b) internal movement and (c) international travel all produce marginal probabilities of permanent firm closure that are positive, statistically significant and consequential. The containment and health index (measuring the overall stringency of the government response) is also positive, statistically significant (at 99\%) and not minimal. The results for these variables confirm the essence of many news reports - that the strength of the government response is related to the permanent closure of a number of firms with the consequent loss of employment.

The statistics on the pandemic itself also contribute to the probability of firm closure. Both the number of cases per million of population and the number of deaths have a marginal effect on probability which is statistically significant (at $99 \%$ confidence) and positive. However, the magnitude of these effects are small. It is also worth noting that the performance of firms before the onset of the pandemic does not seem to have affected the probability of permanent closure. Variables such as productivity, profitability and debt leverage were found to be redundant and were excluded.

Table 3: Probit Analysis of Permanent Closures

Source: Enterprise Surveys, The World Bank, http://www.enterprisesurveys.org 


\begin{tabular}{|c|c|c|}
\hline Variable & Label & Coefficent \\
\hline \multicolumn{3}{|l|}{ Firm level } \\
\hline Firm size: number of employees & empl - & $-0.0001 * *$ \\
\hline 28 & & $(0.0000)$ \\
\hline \multirow{2}{*}{ Years experience of top manager } & mgrexp & $0.0007^{*}$ \\
\hline & & $(0.0004)$ \\
\hline \multirow[t]{2}{*}{ Hospitality sector $(0,1)$} & hospitality & $0.0866^{* * *}$ \\
\hline & & $(0.0318)$ \\
\hline \multicolumn{3}{|l|}{ Country level (by date) } \\
\hline \multirow[t]{2}{*}{ Public transport restrictions } & transpt & $0.1052^{* * *}$ \\
\hline & & $(0.0302)$ \\
\hline \multirow[t]{2}{*}{ Internal movement restrictions } & movemt & $0.2511^{* * *}$ \\
\hline & & $(0.0208)$ \\
\hline \multirow[t]{2}{*}{ International travel restrictions } & travel & $0.3431^{* * *}$ \\
\hline & & $(0.0270)$ \\
\hline \multirow[t]{2}{*}{ Covid cases per million } & casesperm & $0.000002^{* * *}$ \\
\hline & 2) & $(0.0000004)$ \\
\hline \multirow[t]{2}{*}{ Covid deaths } & deaths & $0.000007^{* * *}$ \\
\hline & 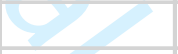 & $(0.0000006)$ \\
\hline \multirow[t]{2}{*}{ Containment and health index } & chindex & $0.0105^{* * *}$ \\
\hline & & $(0.0009)$ \\
\hline Number of observations & & 2388 \\
\hline LR chi2(9) & & 493.3 \\
\hline Prob > chi2 & & 0 \\
\hline Pseudo R2 & & 0.2368 \\
\hline \multicolumn{2}{|l|}{ Standard errors are in parentheses } & \\
\hline \multicolumn{2}{|l|}{ coefficents are marginal effects } & \\
\hline \multicolumn{3}{|c|}{$*$ significant at $90 \%$ confience, $* *$ at $95 \%$ and $* * 99 \%$} \\
\hline
\end{tabular}

Table 4 reports the results of least squares regressions for three employment related firm level variables:

- the proportionate change in sales for the firm (by implication affecting the demand for labour)

- the number of weeks the firm could survive without any sales or support: "survive weeks"

- the change in the share of females in employment between December 2019 and interview: "femshare"

The results suggest the percentage change in firm sales to be related to a number of different variables associated with Covid-19 itself. They are negatively and statistically significantly (at $95 \%$ confidence or higher) related to both the number of cases per million and the number of deaths. As one might expect concerns about the disease itself has an adverse effect on sales but the magnitude of the effect is very small for both variables. As might also be expected the number of weeks of temporary closures was negatively and statistically significantly related (at $99 \%$ confidence) to a change in sales. The effect was not only significant but of some magnitude - typically a reduction of $0.7 \%$ of annual sales for each week closed. As expected there are important and statistically significant differences between sectors. The change in

Source: Enterprise Surveys, The World Bank, http://www.enterprisesurveys.org 
sales was typically about $9.5 \%$ higher for food retailers and pharmacies compared to other firms and almost $10 \%$ lower for hospitality firms. Firm performance indicators before the outbreak of Covid-19 also had statistically significant effects on the change in sales after the outbreak. For productivity (output per worker) and profit per worker these effects, although statistically significant, were very small in magnitude. Firms with fewer competitors also were statistically significantly likely to have a greater (lesser reduction) change in sales. Again, although significant, this effect was modest. Likewise exporting was associated with a greater change (lesser reduction) in sales but the effect was modest. Taken overall the most important effects on sales were sector - an increase in sales for food retail and pharmacies and a reduction in sales for hospitality and those of temporary workplace closures.

Firm closures are a potentially important source of job losses. At the time of the Covid-19 follow-up surveys it was highly unlikely that the full extent of permanent closures had occurred. Firms' responses to the number of weeks that they could survive without any sales or support provides a measure of their vulnerability to closure either since the survey or in the future. In this sense they provide a way of assessing the potential for more recent or future job losses through closures.

Unsurprisingly firms which have received or expect to receive government support have strongly and statistically significantly longer expected survival times. Typically such support adds about one week to the expected survival time. This suggests support, to a point, is effective. Remote working was also found to have a modest but statistically significant positive effect on expected survival times. Firms whose main markets were local or national were found to have statistically significantly lower expected survival times (typically a little over 2 weeks shorter) than those whose main markets were international. As might be expected, indices of the strength of government containment measures had statistically significant effects (at $99 \%$ confidence). Stringent workplace closures typically reduced expected survival times by about 3 weeks, restrictions on internal movement and income support measures by just under 2 weeks. Debt provisions, unsurprisingly, increased expected survival times by about 3 weeks. A number of statistically insignificant variables were excluded in working from general to specific. These included foreign ownership, managerial experience, receipt of a non-governmental loan, exporting and the degree of competition.

The last OLS regression considered the determinants of the change in the share of females in employment attributable to Covid-19. Very few explanatory variables were found to have a statistically significant effect on the share of females in employment. Perhaps this reflects that the overall change was a modest overall reduction in the share of females and that effects varied by country. The results suggest that several variables were statistically significantly (at $90 \%$ or higher) related to a lower share of females in employment. These included the number of workers leaving, the overall change in employment and the initial share of females. None of these effects was pf a substantial magnitude. Variables of note that were removed on grounds of (joint) statistical insignificance included restrictions on internal movement, the number of workers who quit or took leave and the travel sector dummy variable.

Table 4: Least Squares Regression Analysis of Employment Related Covid-19 Effects

Source: Enterprise Surveys, The World

Bank, http://www.enterprisesurveys.org 


\begin{tabular}{|c|c|c|c|c|}
\hline \multirow[t]{2}{*}{ Independent Variables } & \multirow[t]{2}{*}{ Label } & \multicolumn{3}{|c|}{ Dependent Variable } \\
\hline & & Sales change \% & survive weeks & femsharre \\
\hline \multicolumn{5}{|l|}{ A. Country and date specific variables } \\
\hline Number of deaths & deaths & $-0.0001 * *$ & & \\
\hline 2 & & $(0.00005)$ & & \\
\hline Cases per million of population & casesperm & $-0.0001^{* * *}$ & & \\
\hline 282 & & $(0.00004)$ & & \\
\hline \multirow{2}{*}{ Degree of restrictions on workplaces } & work & & $-3.0904^{* *}$ & -0.0939 \\
\hline & & & $(1.3316)$ & $(0.0672)$ \\
\hline \multirow{2}{*}{ Degree of restriction on internal movement } & movemt & & $-1.8435^{* * *}$ & \\
\hline & & & $(0.4693)$ & \\
\hline \multirow{2}{*}{ Strength of income support } & income & & $-1.9546 * * *$ & \\
\hline & & & $(0.4750)$ & \\
\hline \multirow[t]{2}{*}{ Strength of support with debt } & debthelp & & $3.4016^{* *}$ & \\
\hline & & & $(1.6235)$ & \\
\hline \multirow[t]{2}{*}{ Containment and Health Index } & chindex & -0.0328 & $0.0910 * * *$ & 0.0014 \\
\hline & & $(0.0782)$ & $(0.0231)$ & $(0.0012)$ \\
\hline \multicolumn{5}{|l|}{ B. Firm level variables from Covid follow-up surveys } \\
\hline \multirow[t]{2}{*}{ Total number of weeks closed by Round 2} & allweeksclos & $-0.7137^{* * *}$ & -0.0665 & 0.0074 \\
\hline & & $(0.1803)$ & $(0.0485)$ & $(0.0059)$ \\
\hline \multirow[t]{2}{*}{ No government support received or expected $(0,1)$} & nosuppt & & $0.9838^{* *}$ & \\
\hline & & & $(0.4283)$ & \\
\hline \multirow[t]{2}{*}{ Number of workers taking leave or quitting } & leave & & & $-0.0005^{*}$ \\
\hline & & & & $(0.0003)$ \\
\hline \multirow[t]{2}{*}{ Change in labour force from December 2019} & labchange2 & & & $-0.0002^{*}$ \\
\hline & & & & $(0.0001)$ \\
\hline \multirow[t]{2}{*}{ Number of workers laid off } & layoffs & & & -0.0006 \\
\hline & D & & & $(0.0004)$ \\
\hline \multirow[t]{2}{*}{ Proportion of workers working remotely } & remote & & $0.0636 * *$ & \\
\hline & 8 & & $(0.0220)$ & \\
\hline \multirow[t]{2}{*}{ Share of labour working online } & onlineshare & & 0.0237 & \\
\hline & 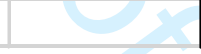 & t & $(0.0173)$ & \\
\hline \multicolumn{5}{|c|}{ C. Firm level characteristics from the Full Enterpride survey (before Covid-19) } \\
\hline Food retail and pharmacies & foodretail & $9.5641 * * *$ & & \\
\hline & & $(1.6057)$ & & \\
\hline Hotels, bars and restaurants $(0,1)$ & hospitality & $-9.8088^{* * *}$ & & \\
\hline & & $(2.9410)$ & & \\
\hline Passenger travel, tiour operators, travel agencies $(0,1)$ & passenger & $8)$ & -1.5979 & \\
\hline & & 82 & $(1.1467)$ & \\
\hline Initial share of females in total employment & femshare19 & 80 & & $-0.0881 * *$ \\
\hline & & 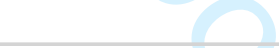 & & $(0.0396)$ \\
\hline Leverage (debt to gross earnings ratio) & leverage & $-0.0039 * *$ & $0.0040 * * *$ & $-0.00007^{* * *}$ \\
\hline & & $(0.0017)$ & $(0.0012)$ & $(0.00001)$ \\
\hline Output per worker & opw & $0.000006 * * *$ & & \\
\hline & & $(0.000003)$ & $\sqrt{3}$ & \\
\hline Profit per worker & ppw & $-0.000006^{* *}$ & 38 & \\
\hline & & $(0.000002)$ & & \\
\hline Number of direct competitors & compet & $-0.0082^{* *}$ & & \\
\hline & & $(0.0039)$ & & \\
\hline Years of experience of top manager & mgrexp & $-0.0730 *$ & & \\
\hline & & $(0.0419)$ & & \\
\hline 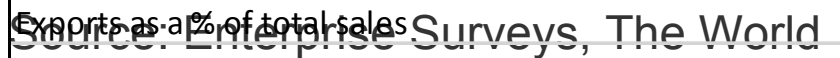 & & $0.0545^{* * *}$ & & \\
\hline Bank, httn: / mann anternrisesurvivis.org & & $(0.0156)$ & & \\
\hline Main markettocal $(0,1)$. & local & & $-2.3863 * * *$ & \\
\hline & & & $(0.6747)$ & \\
\hline Main market national $(0,1)$ & national & & $-2.1529 * * *$ & \\
\hline & & & $(0.6519)$ & \\
\hline
\end{tabular}




\subsection{Seemingly Unrelated Regression (SURE) Estimates}

Table 5 presents the results of a two equation SURE analysis with the dependent variables being "leave" and "furlough" and with each variable included as an independent variable in the equation for determination of the other. This is intended to reduce potential problems of endogeneity arising from a two-way causality between the variables.

As expected the number of workers taking leave or quitting is positively and statistically significantly related to the number furloughed. The magnitude of this effect is moderate, suggesting that for every employee furloughed 0.12 workers take leave or quit their jobs. Of stronger magnitude (and statistically significant at $95 \%$ confidence) is a positive relationship with a lack of government support. The strongest positive effect (on leave and quits) in terms of its magnitude was the sector dummy for food retail and pharmacies (statistically significant at $99 \%$ ). The number of weeks that the firm was closed had a statistically significant (at $99 \%$ ) negative effect on workers leaving or quitting. The effect suggests that every week of firm closure is associated with about 0.4 fewer employees taking leave or quitting. Presumably, there is little sense in taking leave from a firm when it is closed.

With respect to furloughs there was a positive and statistically significant effect (99\%) of the number of workers taking leave or quitting their jobs. This was of some magnitude - for every worker taking leave or quitting about 2.8 employees were furloughed. This suggests that furloughs and leave (or quitting) are, to some extent, substitutes. The proportion of employees working remotely was also positively and statistically significantly (at 99\%) related to the number of furloughs although the effect was of smaller magnitude than for other explanatory variables. A positive and statistically significant (at 95\%) effect of greater magnitude was the $(0,1)$ variable for a decrease in the liquidity of the firm. A decrease in liquidity, as one might expect, was associated with an increase in the number of employees furloughed by more than 8 . Another variable with a positive and statistically significant effect on the number of furloughs was the stringency of government restrictions on internal movement. The number of weeks the firm had been closed was, unsurprisingly, positively and statistically significantly (at 99\%) associated with a greater number of furloughs. For every week of firm closure the results suggest that typically about 2.6 employees were furloughed.

Sector dummy variables for (a) food retail and pharmacies and (b) hospitality had statistically significant negative (at $90 \%$ or higher) effects on the number of furloughs of some magnitude. The results imply that food retail and pharmacies typically furloughed about 18 fewer employees than other sectors and hospitality firms 16 fewer. A lack of government support for the firm also had a statistically significant (at 99\%) negative effect of some consequence, suggesting that unsupported firms furloughed about 14 fewer employees than others. With six different countries the interpretation of this depends on the nature of furlough or similar schemes in each country. To the extent that such a scheme supports the firm then a lack of support would, of course, mean that there would be fewer furloughs. To the extent that the support was provided to the employees then a lack of support to the firm would be less relevant.

Table 5: SURE Analysis

Source: Enterprise Surveys, The World Bank, http://www.enterprisesurveys.org 


\begin{tabular}{|c|c|c|}
\hline \multicolumn{2}{|c|}{ Dependent variable: number of workers taking leave or quitting } & \multirow[b]{2}{*}{$0.1216 * * *$} \\
\hline \multirow[t]{2}{*}{ Number of workers furloughed } & furlough & \\
\hline & & $(0.0041)$ \\
\hline \multirow{2}{*}{ Number of workers laid off } & layoffs & $0.1380^{*}$ \\
\hline & & $(0.0751)$ \\
\hline \multirow{2}{*}{ No government support received or expected $(0,1)$} & nosuppt & $2.1294^{* *}$ \\
\hline & & $(0.8695)$ \\
\hline \multirow{2}{*}{ Food retail and pharmacies } & foodretail & $5.8272 * * *$ \\
\hline & & $(1.6069)$ \\
\hline \multirow{2}{*}{ Total number of weeks closed by Round 2} & allweeksclosed & $;-0.4126 * * *$ \\
\hline & & $(0.0888)$ \\
\hline \multirow{2}{*}{ Degree of restriction to public transport } & transpt & $-1.9300 *$ \\
\hline & & $(1.0189)$ \\
\hline \multirow[t]{2}{*}{ Cases per million of population } & casesperm & $0.00005^{*}$ \\
\hline & & $(0.00002)$ \\
\hline \multirow[t]{2}{*}{ Number of deaths } & deaths & $-0.0001 * * *$ \\
\hline & & $(0.00003)$ \\
\hline \multirow[t]{2}{*}{ Constant } & _cons & 1.4979 \\
\hline & & $(1.5848)$ \\
\hline \multicolumn{2}{|l|}{ Dependent variable: number of workers furloughed } & \\
\hline \multirow[t]{2}{*}{ Number of workers taking leave or quitting } & leave & $2.8479 * * *$ \\
\hline & & $(0.0967)$ \\
\hline \multirow[t]{2}{*}{ Proportion of workers working remotely } & remote & $0.4782 * * *$ \\
\hline & & $(0.1272)$ \\
\hline \multirow[t]{2}{*}{ Decrease in firm liquidity $(0,1)$} & liqdec & $8.2273^{* *}$ \\
\hline & & (3.9595) \\
\hline \multirow{2}{*}{ No government support received or expected $(0,1)$} & nosuppt & $-14.2907 * * *$ \\
\hline & 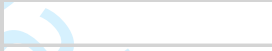 & $(4.1421)$ \\
\hline \multirow[t]{2}{*}{ Food retail and pharmacies } & foodretail & $-17.9956 * *$ \\
\hline & 8 & $(7.8483)$ \\
\hline \multirow[t]{2}{*}{ Hotels, bars and restaurants $(0,1)$} & hospitality & $-15.6516^{*}$ \\
\hline & $(4)>2$ & $(8.1341)$ \\
\hline \multirow[t]{2}{*}{ Total number of weeks closed by Round 2} & allweeksclosed & $2.6426 * * *$ \\
\hline & & $(0.4466)$ \\
\hline \multirow[t]{2}{*}{ Degree of restrictions on workplaces } & work & -28.0409 \\
\hline & & $\{17.1370)$ \\
\hline \multirow[t]{2}{*}{ Degree of restriction on internal movement } & movemt & $8.6203 * * *$ \\
\hline & & $(2.3461)$ \\
\hline \multirow[t]{2}{*}{ Number of deaths } & deaths & $0.0013 * * *$ \\
\hline & & $(0.0002)$ \\
\hline Constant & cons & 40.6592 \\
\hline & & $(33.4091)$ \\
\hline Equation & leave & furlough \\
\hline Observations & 2,001 & 2,001 \\
\hline Parameters & 8 & 10 \\
\hline RMSE & 18.23289 & 88.08017 \\
\hline R-squared & 0.0539 & 0.1034 \\
\hline chi squared & 900.08 & 1028.11 \\
\hline $\mathrm{P}$ & 0.000 & 0.000 \\
\hline Standard errors are in parentheses & & \\
\hline$* * *$ significant at $99 \%$ confidence, $* *$ at $95 \%$ and & $0 \%$ & \\
\hline
\end{tabular}

Source: Enterprise Surveys, The World Bank, http://www.enterprisesurveys.org 


\section{Conclusions}

This study was based on firm responses to survey questionnaires at the early stage of a crisis unprecedented within living memory. There are obvious advantages in seeking to learn lessons from the early stages of the pandemic but there are also obvious constraints. The full economic consequences will take longer to emerge than the pandemic itself and the full consequences for employment will take longer to be evident than many other economic effects.

This study raises concerns about the extent of the loss of employment through permanent closures of firms. Despite efforts to support labour hoarding by firms the early evidence suggests that there is a risk of a significant loss of employment through this means, particularly as the early stages suggest few workers in our sample countries were laid off. The analysis in this study suggests the probability of permanent closure of firms in the early stages to be most closely related to government containment measures. In short many of the early permanent closures can be linked to government measures to contain the virus.

The length of time that firms expect to survive without sales revenues was, on average, a surprisingly short period, often shorter than the average time of temporary closures that had already occurred. For these temporary closures to not become permanent losses of employment will require a degree of liquidity either though government support or nongovernmental loans. Government support schemes do exist and will, most likely, have saved many jobs and firms but the evidence is that employment losses from permanent closure have been of consequence despite these support programmes.

Temporary firm closures, also often as a result of government containment measures, represent a significant loss of labour time. At this stage it is not clear how these costs are shared between workers, firms and government. Furloughs were also common in the countries included in our sample. The analysis presented shows these to be closely related to temporary workplace closures, a lack of government support and liquidity problems. Again, the distribution of costs between firms, workers and government is dependent on the details of the individual schemes. Nonetheless the overall number of furloughs suggest the costs to be substantial.

As one might expect the effects vary considerably by sector. Non-essential retail, hospitality and travel were particularly adversely affected and essential retail less affected. Gender segregation means that these sectors have a higher share of females in the work force and, for most countries in our sample, this resulted in a reduction in the share of females in employment.

From a policy perspective the combination of insufficient liquidity to survive for long periods without sales revenues and temporary closures means that firms are vulnerable to permanent closure. The case for support is based on a stakeholder view not a shareholder one but the harsh realities are that, if the support is either not adequate or well targeted then there would be significant losses in employment through permanent closures. It should come as no surprise that these risks are greatest for certain sectors - non-essential retail, hospitality and travel. Policy also needs to address how the costs of those firms who survive temporary closure. There is a substantial loss of labour weeks and the resulting costs need to be shared by firms, workers and government. Too high a burden on workers will result in workers on leave or quitting. Too high a burden on firm will convert temporary closures to permanent (with a loss of employment).

Source: Enterprise Surveys, The World

Bank, http://www.enterprisesurveys.org 
This paper cannot be definitive. It is based on surveys and analysis at a time when the pandemic, tragically, is far from over. As such its objectives are as much to provide a foundation for further research as to contribute to the existing literature. From an employment perspective it stresses that, although labour hoarding is a highly appropriate objective, the severity of the economic crisis means that firms and workers would require significant and appropriate support to avoid large losses of employment. Some of the details of how this might be achieved do need further research. A particular limitation of this study are important differences between countries in the policy response to Covid-19 that are not captured by the containment policy indices. In particular, it is outside the scope of this study why one country chooses a different set of policy responses to another or even to provide a detailed catalogue of these differences. Further research on the matter would be of considerable value. Although the methodological approach used a general to specific approach to reduce the risk of bias arising from an omitted confounding variable it is not possible, as with most studies, to be certain that such a confounding variable is absent.

For example, this study shows that commercial loans as well as direct government support do help vulnerable firms. The catch is that lenders may be reluctant to lend to those that are vulnerable. The relative advantages of government loan guarantees and of direct funding from government needs closer examination. Likewise, it is not yet clear how furloughs work - do workers respond by using the time to look for other employment or do they provide the labour hoarding intended? That is, furloughs can only work as intended only if workers expect that their job will be there after the pandemic. The analysis clearly shows that government measures necessary to save lives from the pandemic do hit firms and the resulting loss of liquidity hits labour markets and employment in particular. Of the various containment measures workplace closures and restrictions on internal movement do seem to have had the strongest impact. Avoiding permanent firm closures is important for longer term recovery of employment. Our results suggest that the expected survival time of firms was significantly increased by the provision of government support.

Source: Enterprise Surveys, The World Bank, http://www.enterprisesurveys.org 


\section{References}

Baldwin, R. and Freeman, R. (2020), Supply chain contagion waves: Thinking ahead on manufacturing 'contagion and reinfection' from the COVID concussion, VoxEU.org, 1 April.

Baldwin, R. and Tomiura, E. (2020), Thinking Ahead about the Trade Impact of COVID-19, in Baldwin, R. and Weder di Mauro, B. (eds), Economics in the Time of COVID-19, CEPR Press.

Balleer, A., Gehrke, B., Lechthaler, W., Merkl, C. (2016), Does short-time work save jobs? A business cycle analysis, European Economic Review, 84, 99-122.

Bartik, A.W., Bertrand, M., Lin, F., Rothstein, J. and Unrath, M. (2020), Measuring the labor market at the onset of the COVID-19 crisis, NBER Working Paper No. 27613 July.

Böckerman, P., \& Ilmakunnas, P. (2012). The job satisfaction-productivity nexus: A study using matched survey and register data. ILR Review, 65(2), 244-262.

Borland, J. and Charlton, A. (2020), The Australian Labour Market and the Early Impact of COVID-19: An Assessment. The Australian Economic Review, 53: 297324. https://doi.org/10.1111/1467-8462.12386

Branicki et al., 2018 L.J. Branicki, B. Sullivan-Taylor, S.R. Livschitz (2018), How entrepreneurial resilience generates resilient SMEs, Int. J. Entrep. Behav. Res., 24 (7): 1244-1263

Cajner, T., Crane, L. D., Decker, R. A., Grigsby, J., Hamins-Puertolas, A., Hurst, E., Kurz, C., \& Yildirmaz, A. (2020), The U.S. Labor Market during the Beginning of the Pandemic Recession. Working Paper 27159, National Bureau of Economic Research.

Campos, J., Ericsson, N. R., \& Hendry, D. F. (2005). Introduction: General to- Specific Modelling.(1-81). Cheltenham, UK: Edward Elgar

Correia, S., Luck, S. and Verner, E. (2020), Pandemics Depress the Economy, Public Health Interventions Do Not: Evidence from the 1918 Flu, (5 June).

Coskun, S. and Husnu, D. (2020), The Emergence of Procyclical Fertility: The Role of Gender Differences in Employment Risk, CRC TR 224 Discussion Paper Series No. 142.

Davis, S. J., \& Haltiwanger, J. (1999). On the driving forces behind cyclical movements in employment and job reallocation. American Economic Review, 89(5), 1234-1258.

Dingel, J. I. \& Neiman, B. (2020). How many jobs can be done at home? Technical report, National Bureau of Economic Research.

Eggers, F. (2020), Masters of disasters? Challenges and opportunities for SMEs in times of crisis, J. Bus. Res., 116 (2020), pp. 199-208

Ehrenberg, R. G., \& Smith, R. S. (2012). Modern labor economics. Theory and public policy (11 ed.), Pearson Education.

Espitia, A., Mattoo, A., Rocha, N., Ruta, M. and Winkler, D. (2021), Pandemic Trade: Covid-19, Remote Work and Global Value Chains, The World Economy, https://doi.org/10.1111/twec.13117 (published online 17 February).

Source: Enterprise Surveys, The World

Bank, http://www.enterprisesurveys.org 
Friedt, L. F. and Zhang, K. (2021), "The triple effect of Covid-19 on Chinese exports: First evidence of the export supply, import demand and GVC contagion effects", in COVID Economics Vetted and Real-Time Papers, Issue 53 (23 October), CEPR Press.

Gossling, S., Scott, D. and Hal, M. (2020) Pandemics, tourism and global change: a rapid assessment of COVID-19, Journal of Sustainable Tourism, 29 (1): 20-29.

Haltiwanger, J., Scarpetta, S., \& Schweiger, H. (2014). Cross country differences in job reallocation: The role of industry, firm size and regulations. Labour Economics, 26, 11-25.

Hassan, T.A. and Hollander, S., van Lent, L. Schwedeler, M., and Tahoun, A. (2020), Firm-level Exposure to Epidemic Diseases: Covid-19, SARS, and H1N1, National Bureau of Economic Research Working Paper Series, April.

Hayakawa, K. and Mukunoki, H. (2020), "Impacts of COVID-19 on global value chains", IDEJETRO Discussion Paper No. 797, September 2020.

Hevia, C. and Neumeyer, A. (2020), "A perfect storm: COVID-19 in emerging economies", Vox eBook Chapters, in Djankov, Simeon and Panizza, Ugo (eds), COVID-19 in Developing Economies, first edition, 1 (1): 25-37, Centre for Economic Policy Research.

Hoover, K. D., \& Perez, S. J. (1999). Data mining reconsidered: encompassing and the general-to-specific approach to specification search. The Econometrics Journal, 2(2), 167191.

Kuckertz, A., Brändle, L., Gaudig, A., Hinderer, S., Arturo Morales Reyes, C., Prochotta, A., Steinbrink, K., Berger, E.S.C (2020), Startups in times of crisis - A rapid response to the COVID-19 pandemic, Journal of Business Venturing Insights, 13, e00169.

Lakatos, A. (2020), Impact of the coronavirus pandemic on international trade, online access https://www.tradeeconomics.com/iec_publication/impact-of-the-coronaviruspandemic-on-international-trade/.

Maliszewska, M., Mattoo, A. and van der Mensbrugghe, D. (2020), The Potential Impact of COVID-19 on GDP and Trade: A Preliminary Assessment, World Bank Policy Research Working Paper No. 9211.

Matthias, D. and Tertilt, M. (2016) Families in Macroeconomics, Chapter 23 of Handbook of Macroeconomics, Vol. 2. North Holland

McKibbin, W. J. and Fernando, R. (2020), Global Macroeconomic Scenarios of the COVID-19 Pandemic, (June 25), CAMA Working Paper No. 62/2020.

Mongey, S., Pilossoph, L., \& Weinberg, A. (2020). Which Workers Bear the Burden of Social Distancing Policies? Technical report, National Bureau of Economic Research

Montenovo, L., Jiang, X., Rojas, F. L., Schmutte, I. M., Simon, K. I., Weinberg, B. A., \& Wing, C. (2020). Determinants of Disparities in Covid-19 Job Losses. Technical report, National Bureau of Economic Research.

OECD (2020a), Economic Outlook No. 107 - Double-hit scenario, Paris.

OECD (2020b), Economic Outlook 2, Turning hope into reality, Paris.

Ozge, A., Gianluca, B. and Queralto, A. (2020), Modeling the Global Effects of the COVID-19 Sudden Stop in Capital Flows, FEDS Notes, (2 July), accessed 
https://www.federalreserve.gov/econres/notes/feds-notes/modeling-the-globaleffects-of-the-covid-19-sudden-stop-in-capital-flows-20200702.htm.

R. Pal, H. Torstensson, H. Mattila (2014) Antecedents of organizational resilience in economic crises-an empirical study of Swedish textile and clothing SMEs, Int. J. Prod. Econ., 147: 410-428.

Radlińska, K., Klonowska-Matynia, M., Jakubowska, A., \& Kwiatkowski, G. (2020). Labor hoarding: an old phenomena in modern times? Case study for EU countries. Journal of Business Economics and Management, 21(3): 872-889.

Vella, M. (2018), Employment and labour hoarding: a production function approach. Journal of Economics, Finance and Administrative Science, 23 (46): 230-246.

Wolf, A. (2020, June 11). Stores, restaurants, and companies across the US are putting staff on furlough as they shut down during the coronavirus outbreak - here's what it means for employees. https://www.businessinsider.com/what-is-employee-furlough-howdoes-it-work-employees

World Bank (2020), 2020 Year in Review: The impact of COVID-19 in 12 charts, Washington, D.C.

WTO (2020a), The Economic Impact of COVID-19 on women in vulnerable sectors and economies, Information note, 3 August 2020, Geneva.

WTO (2020b), Trade shows signs of rebound from COVID-19, recovery still uncertain, PRESS/862, October.

Zellner, A. (1963). Estimators for seemingly unrelated regression equations: Some exact finite sample results. Journal of the American Statistical Association, 58(304), 977-992.

Source: Enterprise Surveys, The World Bank, http://www.enterprisesurveys.org 


\section{Appendix 1: Firm Closures}




\begin{tabular}{|c|c|c|c|c|c|c|}
\hline & Croatia & Cyprus & Greece & Italy & Malta & Portugal \\
\hline & Sep-20 & Dec-20 & Nov-20 & Dec-20 & Jan-21 & Oct-20 \\
\hline \multicolumn{7}{|c|}{ Mean \% of firms confirmed or assumed permanently closed } \\
\hline All & 13.86 & 20.00 & 6.87 & 36.14 & 1.59 & 23.62 \\
\hline Small (5-19) & 13.52 & 22.14 & 7.69 & 35.93 & 1.14 & 24.44 \\
\hline Medium (20-99) & 14.66 & 11.52 & 4.49 & 37.22 & 1.20 & 22.57 \\
\hline Large $(100+)$ & 14.03 & 20.52 & 1.37 & 34.29 & 5.82 & 15.50 \\
\hline Manufacturing & 12.97 & 21.43 & 4.24 & 26.39 & 1.00 & 21.38 \\
\hline Services & 14.15 & 19.54 & 7.42 & 40.55 & 1.75 & 24.48 \\
\hline Retail & 14.93 & 30.51 & 4.16 & 43.48 & & 21.43 \\
\hline Other Services & 13.23 & 16.43 & 8.63 & 39.67 & & 25.63 \\
\hline Direct exports are $10 \%$ or more of sales & 14.23 & 26.47 & 0.40 & 17.67 & 1.31 & 27.92 \\
\hline Non-exporter & 13.78 & 19.46 & 8.08 & 37.94 & 1.66 & 23.17 \\
\hline Top manager is female & 17.07 & 19.45 & 11.36 & 36.49 & 0.00 & 27.77 \\
\hline Top manager is male & 12.67 & 20.05 & 5.94 & 36.07 & 1.79 & 22.94 \\
\hline $10 \%$ or more foreign ownership & 12.60 & 30.63 & 0.36 & 51.50 & 0.00 & 45.53 \\
\hline Domestic & 13.92 & 19.74 & 7.37 & 35.38 & 1.74 & 22.60 \\
\hline \multicolumn{7}{|c|}{ Mean \% of firms confirmed permanently closed simce Covid-19 } \\
\hline 28 & 0.09 & 0.18 & 0.03 & 5.14 & 0.53 & 2.01 \\
\hline Small (5-19) & 0.00 & 0.00 & 0.04 & 5.67 & 0.00 & 2.68 \\
\hline Medium (20-99) & 0.32 & 0.91 & 0.00 & 3.85 & 0.66 & 0.26 \\
\hline Large $(100+)$ & 0.00 & 0.00 & 0.00 & 0.00 & 2.91 & 0.21 \\
\hline Manufacturing & 0.00 & 0.00 & 0.20 & 1.44 & 0.00 & 1.31 \\
\hline Services & 0.12 & 0.23 & 0.00 & 6.82 & 0.67 & 2.28 \\
\hline Other Services & 0.25 & 0.30 & 0.00 & 7.98 & & 2.96 \\
\hline Retail & 0.00 & 0.00 & 0.00 & 2.90 & & 0.47 \\
\hline Direct exports are $10 \%$ or more of sales & 0.49 & 0.00 & 0.00 & 3.14 & 0.00 & 0.09 \\
\hline Non-exporter & 0.00 & 0.00 & 0.04 & 4.67 & 0.66 & 2.21 \\
\hline Top manager is female & 0.00 & 0.00 & 0.00 & 4.32 & 0.00 & 2.57 \\
\hline Top manager is male & 0.12 & 0.19 & 0.04 & 5.29 & 0.60 & 1.92 \\
\hline $10 \%$ or more foreign ownership & 1.85 & 0.00 & 0.00 & 0.00 & 0.00 & 1.44 \\
\hline Domestic & 0.00 & 0.18 & 0.04 & 4.54 & 0.58 & 2.04 \\
\hline \multicolumn{7}{|c|}{$\%$ of firms that have ever temporarily closed during the COVID-19 outbreak } \\
\hline All & 29.69 & 44.83 & 49.71 & 66.10 & 28.36 & 34.86 \\
\hline Small (5-19) & 31.96 & 47.34 & 53.68 & 69.12 & 30.03 & 35.16 \\
\hline Medium (20-99) & 25.84 & 31.94 & 39.64 & 56.87 & 26.91 & 34.91 \\
\hline Large $(100+)$ & 23.68 & 56.95 & 19.21 & 46.36 & 24.99 & 30.16 \\
\hline Manufacturing & 20.42 & 50.69 & 31.05 & 70.72 & 9.40 & 26.47 \\
\hline Services & 32.77 & 42.91 & 53.87 & 63.60 & 33.29 & 38.27 \\
\hline Other Services & 43.87 & 39.53 & 51.35 & 68.11 & & 42.57 \\
\hline Retail & 23.21 & 56.78 & 60.66 & 46.95 & & 27.72 \\
\hline Direct exports are $10 \%$ or more of sales & 18.86 & 7.15 & 42.50 & 51.30 & 27.80 & 33.36 \\
\hline Non-exporter & 32.00 & 46.55 & 51.19 & 68.78 & 28.48 & 35.00 \\
\hline Top manager is female & 24.27 & 67.03 & 53.08 & 74.54 & 45.11 & 40.27 \\
\hline Top manager is male & 31.58 & 42.77 & 49.06 & 64.57 & 25.94 & 34.00 \\
\hline $10 \%$ or more foreign ownership & 47.90 & 79.35 & 48.23 & 11.98 & 14.66 & 31.37 \\
\hline Domestic & 28.76 & 43.64 & 49.84 & 66.72 & 28.84 & 35.01 \\
\hline \multicolumn{7}{|c|}{ If closed temporarily, average total duration of closure (weeks) } \\
\hline All & 6.94 & 10.62 & 9.10 & 10.20 & & 6.11 \\
\hline Small (5-19) & 6.77 & 6.64 & 9.04 & 10.86 & & 5.91 \\
\hline Medium (20-99) & 7.40 & & 9.24 & 7.06 & & 5.92 \\
\hline Large $(100+)$ & 7.05 & & 14.02 & 10.15 & & 10.74 \\
\hline Manufacturing & 6.26 & & 9.67 & 8.33 & & 4.46 \\
\hline Services & 7.08 & 11.04 & 9.04 & 11.42 & & 6.57 \\
\hline Other Services & 6.97 & 11.69 & 8.66 & 12.08 & & 7.21 \\
\hline Retail & 7.25 & & 9.70 & 9.69 & & 4.17 \\
\hline Direct exports are $10 \%$ or more of sales & 8.51 & & 9.63 & 7.77 & & 4.75 \\
\hline 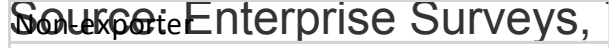 & The.7bl & ICho.62 & 9.08 & 10.54 & & 6.23 \\
\hline Pog mknabertipfdndevw enternrises & IrvPe95.s. & & 10.95 & 12.92 & & 4.96 \\
\hline Top manager is male & 6.37 & 11.46 & 8.79 & 9.48 & & 6.32 \\
\hline $10 \%$ or more foreign ownership & 9.03 & & & & & 8.47 \\
\hline Domestic & 6.76 & 6.67 & 9.03 & 10.21 & & 6.02 \\
\hline
\end{tabular}


Appendix 2: Changes in the Way of Working

\begin{tabular}{|c|c|c|c|c|c|c|}
\hline & Croatia & Cyprus & Greece & Italy & Malta & Portugal \\
\hline & Sep-20 & Dec-20 & Nov-20 & Dec-20 & Jan-21 & Oct-20 \\
\hline \multicolumn{7}{|c|}{$\%$ of firms that started or increased online business activity } \\
\hline All & 12.64 & 26.62 & 29.88 & 22.69 & 27.93 & 13.61 \\
\hline Small (5-19) & 11.42 & 24.68 & 26.31 & 17.44 & 26.21 & 13.99 \\
\hline Medium (20-99) & 14.15 & 34.90 & 43.49 & 44.57 & 31.83 & 6.86 \\
\hline Large $(100+)$ & 18.00 & 22.74 & 13.82 & 17.53 & 18.94 & 42.44 \\
\hline Manufacturing & 10.87 & 21.46 & 14.94 & 23.17 & 16.62 & 6.38 \\
\hline Services & 13.23 & 28.30 & 33.23 & 22.42 & 30.87 & 16.55 \\
\hline Retail & 8.85 & 45.10 & 62.90 & 22.11 & & 17.29 \\
\hline Other Services & 18.33 & 24.20 & 22.31 & 22.50 & & 16.24 \\
\hline Direct exports are $10 \%$ or more of sales & 14.64 & 18.69 & 19.74 & 19.92 & 26.90 & 18.96 \\
\hline Non-exporter & 12.21 & 27.02 & 31.97 & 23.28 & 28.14 & 13.13 \\
\hline Top manager is female & 17.87 & 15.76 & 37.68 & 19.29 & 52.14 & 9.06 \\
\hline Top manager is male & 10.81 & 27.62 & 28.36 & 23.30 & 24.42 & 14.34 \\
\hline $10 \%$ or more foreign ownership & 38.95 & 11.37 & 44.92 & 2.81 & 18.28 & 9.07 \\
\hline Domestic & 11.31 & 26.80 & 28.57 & 22.93 & 28.17 & 13.79 \\
\hline \multicolumn{7}{|c|}{$\%$ of firms that started or increased delivery of goods, services or carryout } \\
\hline All & 4.55 & 26.62 & 31.26 & 20.46 & 16.76 & 22.61 \\
\hline Small (5-19) & 4.56 & 24.68 & 28.98 & 21.33 & 19.33 & 23.35 \\
\hline Medium (20-99) & 4.15 & 34.90 & 41.22 & 17.51 & 15.78 & 20.58 \\
\hline Large (100+) & 5.93 & 22.74 & 8.77 & 16.81 & 5.00 & 21.96 \\
\hline Manufacturing & 4.16 & 21.46 & 12.77 & 10.79 & 21.09 & 18.95 \\
\hline Services & 4.68 & 28.30 & 35.39 & 25.80 & 15.63 & 24.10 \\
\hline Retail & 6.02 & 45.10 & 44.58 & 39.08 & & 20.70 \\
\hline Other Services & 3.12 & 24.20 & 51.15 & 22.15 & & 25.48 \\
\hline Direct exports are $10 \%$ or more of sales & 4.74 & 18.69 & 10.57 & 6.52 & 7.38 & 15.40 \\
\hline Non-exporter & 4.51 & 27.02 & 35.51 & 22.72 & 18.65 & 23.26 \\
\hline Top manager is female & 8.28 & 15.76 & 49.61 & 31.39 & 27.03 & 25.64 \\
\hline Top manager is male & 3.24 & 27.62 & 27.67 & 18.48 & 15.27 & 22.13 \\
\hline $10 \%$ or more foreign ownership & 8.10 & 11.37 & 33.23 & 0.00 & 4.81 & 35.60 \\
\hline Domestic & 4.37 & 26.80 & 31.08 & 20.69 & 17.08 & 22.07 \\
\hline \multicolumn{7}{|c|}{$\%$ of firms that started or increased remote work } \\
\hline All & 23.74 & 34.81 & 30.68 & 33.49 & 47.06 & 18.32 \\
\hline Small (5-19) & 23.92 & 27.50 & 21.67 & 26.88 & 31.65 & 11.89 \\
\hline Medium (20-99) & 14.65 & 47.68 & 59.15 & 53.08 & 57.86 & 27.37 \\
\hline Large (100+) & 56.46 & 81.24 & 49.31 & 79.91 & 91.91 & 68.27 \\
\hline Manufacturing & 24.26 & 25.15 & 32.59 & 44.79 & 35.10 & 19.48 \\
\hline Services & 23.57 & 37.98 & 30.26 & 27.20 & 50.16 & 17.85 \\
\hline Retail & 16.22 & 20.42 & 24.05 & 13.33 & & 12.17 \\
\hline Other Services & 32.10 & 42.27 & 32.55 & 30.91 & s & 20.16 \\
\hline Direct exports are $10 \%$ or more of sales & 30.54 & 56.01 & 50.52 & 56.74 & 71.56 & 32.12 \\
\hline Non-exporter & 22.29 & 33.99 & 26.65 & 30.15 & 42.11 & 17.08 \\
\hline Top manager is female & 31.79 & 9.04 & 17.93 & 23.79 & 48.30 & 14.42 \\
\hline Top manager is male & 20.93 & 37.21 & 33.15 & 35.26 & 46.88 & 18.94 \\
\hline $10 \%$ or more foreign ownership & 51.67 & 100.00 & 63.28 & 99.00 & 85.45 & 50.58 \\
\hline Domestic & 22.32 & 32.70 & 27.87 & 32.87 & 45.09 & 16.93 \\
\hline
\end{tabular}

Source: Enterprise Surveys, The World Bank, http://www.enterprisesurveys.org 


\section{Appendix 3: Proportion of Firms Changing Employment Levels}




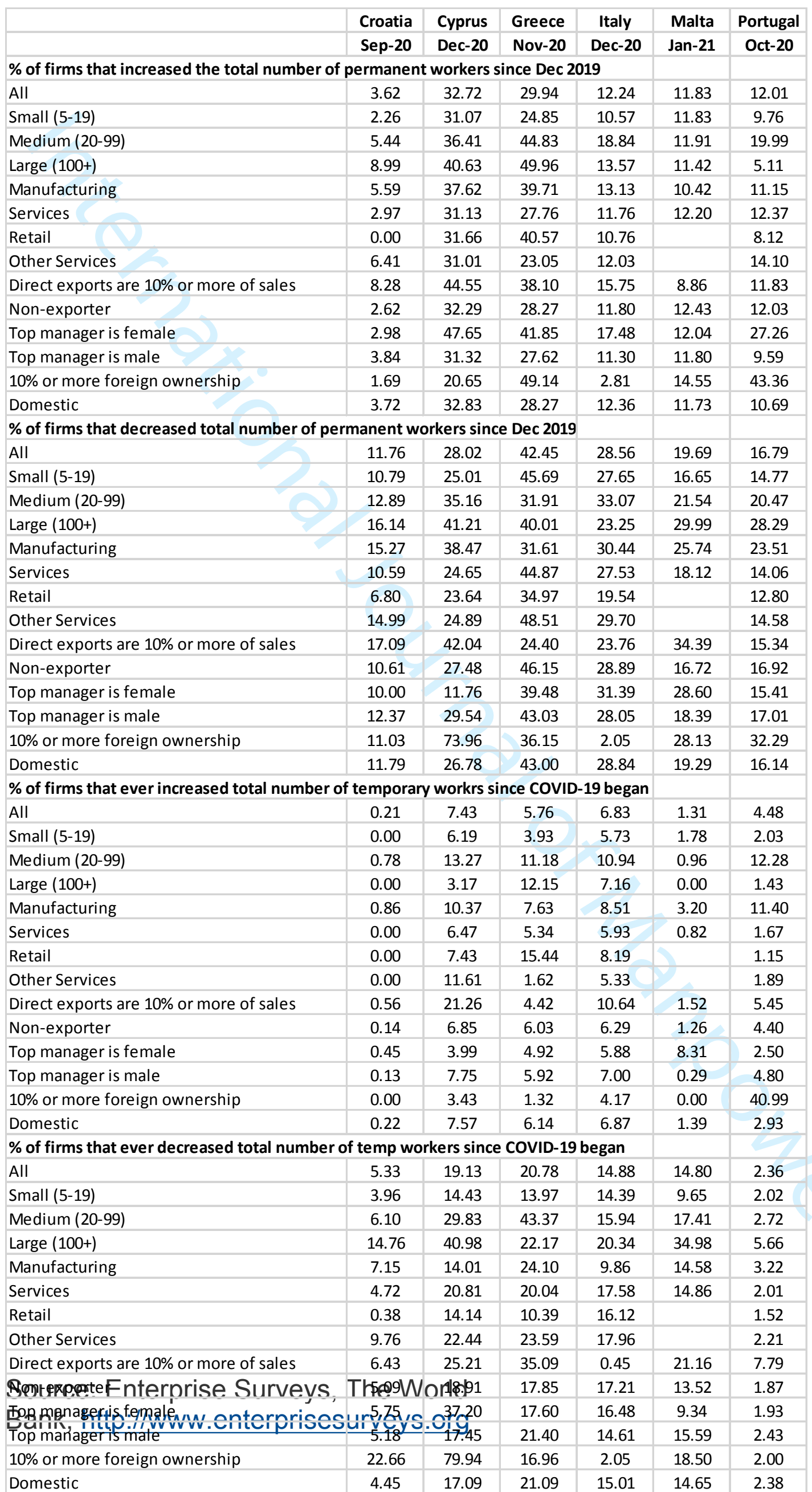


Appendix 4: Female Employment and Furloughs (Averages by Firm)

\begin{tabular}{|c|c|c|c|c|c|c|}
\hline \multirow[t]{3}{*}{ 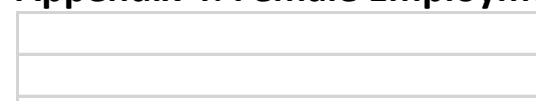 } & \multirow{3}{*}{$\begin{array}{l}\text { Croatia } \\
\text { Sep-20 }\end{array}$} & \multirow{3}{*}{$\begin{array}{l}\text { Cyprus } \\
\text { Dec-20 }\end{array}$} & \multirow{3}{*}{\begin{tabular}{|l|} 
Greece \\
Nov-20
\end{tabular}} & \multirow{3}{*}{\begin{tabular}{|c|} 
Italy \\
Dec-20
\end{tabular}} & \multirow{3}{*}{$\begin{array}{l}\text { Malta } \\
\text { Jan-21 }\end{array}$} & \multirow{3}{*}{$\begin{array}{c}\text { Portugal } \\
\text { Oct-20 }\end{array}$} \\
\hline & & & & & & \\
\hline & & & & & & \\
\hline \multicolumn{6}{|c|}{ Percentage point change since Dec 2019 in the proportion perm full-time workers that are female } & \\
\hline All & -0.12 & -0.70 & -0.05 & 1.31 & 0.67 & -0.22 \\
\hline Small (5-19) & -0.01 & -0.93 & -0.26 & 1.68 & 0.06 & -0.37 \\
\hline Medium (20-99) & -0.43 & 5.77 & 0.70 & -0.01 & 2.35 & 0.09 \\
\hline Large $(100+)$ & 0.04 & -18.33 & -0.52 & 0.10 & -4.07 & 0.38 \\
\hline Manufacturing & 0.14 & 0.32 & -1.77 & 0.82 & -0.94 & 0.29 \\
\hline Services & -0.21 & -1.03 & 0.34 & 1.58 & 1.09 & -0.44 \\
\hline Retail & -0.13 & -0.24 & -1.66 & 1.46 & & 1.44 \\
\hline Other Services & -0.30 & -1.23 & 1.07 & 1.61 & & -1.21 \\
\hline Direct exports are $10 \%$ or more of sales & -1.82 & -1.95 & -7.06 & 1.61 & -3.05 & 1.11 \\
\hline Non-exporter & 0.24 & -0.63 & 1.39 & 1.27 & 1.42 & -0.35 \\
\hline Top manager is female & -0.34 & 2.47 & 1.10 & 5.47 & 4.05 & 1.33 \\
\hline \multirow{2}{*}{$\begin{array}{l}\text { Top manager is male } \\
10 \% \text { or more foreign ownership }\end{array}$} & -0.04 & -0.95 & -0.27 & 0.57 & 0.18 & -0.47 \\
\hline & 0.15 & -46.44 & 3.46 & 0.01 & -1.17 & 1.42 \\
\hline Domestic & -0.13 & 0.60 & -0.35 & 1.33 & 0.77 & -0.30 \\
\hline \multicolumn{7}{|c|}{ Proportion of female workers among the workers furloughed } \\
\hline All & 46.61 & 41.28 & 46.94 & 31.29 & 32.93 & 46.64 \\
\hline Small (5-19) & 50.49 & 37.99 & 47.76 & 31.72 & & 40.62 \\
\hline Medium (20-99) & 25.92 & 56.41 & 43.53 & 28.02 & & 56.67 \\
\hline Large (100+) & 60.48 & 48.40 & 50.24 & 40.22 & & 48.96 \\
\hline Manufacturing & 49.40 & 44.02 & 43.39 & 27.04 & & 56.18 \\
\hline Services & 45.65 & 40.08 & 47.69 & 33.07 & 40.55 & 43.48 \\
\hline Retail & 68.40 & 64.77 & 62.91 & 59.68 & & 37.83 \\
\hline Other Services & 31.01 & 33.54 & 42.39 & 26.30 & & 44.88 \\
\hline Direct exports are $10 \%$ or more of sales & 21.21 & 52.83 & 42.94 & 26.42 & & 43.71 \\
\hline Non-exporter & 50.99 & 40.16 & 47.69 & 32.19 & 30.64 & 46.98 \\
\hline Top manager is female & 60.41 & 64.95 & 54.75 & 54.39 & & 68.16 \\
\hline Top manager is male & 39.12 & 38.32 & 45.39 & 27.32 & 33.57 & 45.14 \\
\hline $10 \%$ or more foreign ownership & & C & 32.70 & 71.56 & & 75.91 \\
\hline Domestic & 44.01 & 40.04 & 47.55 & 31.49 & 30.00 & 44.57 \\
\hline
\end{tabular}

Source: Enterprise Surveys, The World Bank, http://www.enterprisesurveys.org 
Appendix 5: Governmant Support

\begin{tabular}{|c|c|c|c|c|c|c|}
\hline & Croatia & Cyprus & Greece & Italy & Malta & Portugal \\
\hline & Sep-20 & Dec-20 & Nov-20 & Dec-20 & Jan-21 & Oct-20 \\
\hline \multicolumn{7}{|c|}{$\%$ of firms that received/expect to receive national or local govt assistance } \\
\hline 2 & 60.59 & 75.95 & 84.42 & 78.02 & 76.69 & 30.75 \\
\hline Small (5-19) & 59.57 & 72.94 & 86.97 & 79.31 & 72.88 & 27.61 \\
\hline Medium (20-99) & 61.47 & 81.91 & 77.04 & 72.69 & 78.29 & 33.44 \\
\hline Large (100+) & 66.39 & 92.85 & 73.36 & 78.56 & 93.34 & 64.61 \\
\hline Manufacturing & 67.68 & 86.02 & 87.92 & 74.77 & 66.14 & 28.84 \\
\hline Services & 58.23 & 72.65 & 83.64 & 79.80 & 79.43 & 31.51 \\
\hline+8 & 45.74 & 68.14 & 67.77 & 69.25 & & 29.74 \\
\hline Other Services & 72.73 & 73.76 & 89.55 & 82.65 & & 32.22 \\
\hline Direct exports are $10 \%$ or more of sales & 69.27 & 75.90 & 88.92 & 65.02 & 72.94 & 36.74 \\
\hline Non-exporter & 58.73 & 76.13 & 83.50 & 80.49 & 77.45 & 30.21 \\
\hline Top manager is female & 46.32 & 89.68 & 83.97 & 77.37 & 74.04 & 27.91 \\
\hline Top manager is male & 65.57 & 74.67 & 84.50 & 78.14 & 77.07 & 31.21 \\
\hline $10 \%$ or more foreign ownership & 71.71 & 88.75 & 74.73 & 30.95 & 78.65 & 20.02 \\
\hline Domestic & 60.02 & 75.49 & 85.26 & 78.57 & 76.48 & 31.10 \\
\hline
\end{tabular}

Source: Enterprise Surveys, The World Bank, http://www.enterprisesurveys.org 
